\title{
EI Imperio Otomano y la política de alianzas: las relaciones franco- otomanas en el tránsito del siglo XVI al XVII*
}

\author{
Evrim Türkçelik \\ Ankara Social Sciences University
}

RESUMEN: Aunque la historiografía occidental considera al Imperio Otomano como un factor marginal, un simple antagonista, la Sublime Puerta es un elemento esencial en la historia de la Edad Moderna. La concienzuda política de equilibrio con respecto a los poderes cristianos convertía a los otomanos en un elemento crucial en la lucha por la hegemonía. La alianza franco-turca que se estableció en los reinados de Francisco I y Solimán el Magnífico principalmente dependía de la mutua enemistad contra la hegemonía de los Habsburgo en Europa. A finales del siglo XVI, después de la muerte de Enrique III las guerras de religión en Francia dieron pie a una situación caótica en que el Rey Católico buscó la oportunidad de situar a Francia bajo su control. Esto conllevaría un cambio irremediable en el equilibrio de poderes en el Mediterráneo, situación inadmisible para los intereses geoestratégicos de los sultanes otomanos. Los otomanos desempeñaron un papel importante en la politica exterior francesa contra las pretensiones españolas a lo largo de las diferentes fases del reinado de Enrique IV. Incluso Clemente VIII instrumentalizó implícitamente la amistad turco-francesa para fortalecer su propia posición, como la de Francia, respecto a la Monarquía Hispana. El presente artículo pretende demostrar los límites y la eficacia de la política de alianzas entre Francia y el Imperio Otomano en el tránsito del siglo XVI al XVII, reseñando también el papel de Inglaterra y la República de Venecia.

\section{Palabras Clave: Imperio Otomano; Enrique IV de Francia; Cle- mente VIII; Alianza franco-otomana.}

* Abreviaturas utilizadas: AGS: Archivo General de Simancas; ASVe: Archivio di Stato di Venezia; BOA: Başbakanlık Osmanlı Arşivi; SDC: Senato Dispacci Constantinopoli; CSPV: Calendar of State Papers, Venetian. 
The Ottoman Empire and the policy of alliances: Franco-Ottoman relations in the transition from the XVIth to XVIIth centuries

ABSTRACT: Although Western historiography considered the Ottoman Empire as a marginal and antagonist factor, the Ottomans were an integral component of the history of Early Modern age. The conscientious policy of balance of power towards the Christian powers made Ottomans a crucial element in the struggle for hegemony. The Franco-Turkish alliance that was established in the reigns of Francis I and Suleiman the Magnificent mainly depended on mutual enmity against Spanish hegemony in Europe. In the late sixteenth century, after the death of Henry III the French Wars of Religion gave rise to a chaotic situation in which the Catholic King sought the opportunity to place France under its control. This could have caused an irreversible change in the balance of power in the Mediterranean, an unacceptable situation for the geostrategic interests of the Ottoman sultans. The Ottoman Empire played a major role in the French foreign policy against Spanish claims during the different phases of the reign of Henry IV. Even Clement VIII implicitly instrumentalized Ottoman-French friendship to strengthen both its own position as well as that of France with respect to the Spanish Monarchy. This article aims to demonstrate the limits and efficiencies of politics of alliance in the transition from the sixteenth to the seventeenth century considering the role of England and the Republic of Venice.

KEY WORDS: Ottoman Empire; Henry IV of France; Clemente VIII; Ottoman-French Alliance.

En este estudio se pretende analizar las diferentes fases de la tradicional alianza franco-turca a lo largo del reinado de Enrique IV en el contexto general de la época, determinada por la Larga Guerra de Hungría. La evolución de la relación del Imperio Otomano con la República de Venecia y en menor parte, con Inglaterra serán aspectos que intentaremos referir en paralelo a las relaciones franco-otomanas en el tránsito del siglo XVI al XVII.

Desde la época de Solimán el Magnífico, el Imperio Otomano adoptó una posición pro-francesa y pro-protestante como parte de su política contra el bloque Habsburgo en la lucha del equilibrio de poder en Europa ${ }^{1}$. Su objetivo era asegurar que ninguno de los príncipes cristianos pudiera unificar la cristiandad y frenar el avance otomano ${ }^{2}$. La alianza turco-francesa empezó a ser una realidad de la política exterior gala desde la batalla de Pavía y representó un contrapeso indispensable contra el poder de los Habsburgo, además de proporcionar ventajas comerciales a los mercaderes franceses en Levante.

1 VAUGHAN, 1954. El presente artículo se inscribe en los resultados del Proyecto de Investigación HAR2009-09991. FISHER-GALATI, 1959. COLES, 1968.

${ }^{2}$ HUREWITZ, 15/2 (Washington, 1961): 141-152. 
Durante las Guerras de Religión las relaciones franco-otomanas se enfriaron bastante, y en la década de 1580 la tradicional amistad entre la Sublime Puerta y el Rey Cristianísimo se encuentra en un punto crítico como consecuencia del caos interior en Francia, del acercamiento turco-inglés, de la tregua turcoespañola y de la guerra turco-persa. A comienzos de la última década del siglo XVI, la candidatura del protestante Enrique de Navarra (Enrique IV) al trono francés, después de la muerte de Enrique III en 1589 y el final de la larga guerra persa-otomana en 1590, complicó el contexto político del Viejo Mundo3.

La candidatura del protestante Enrique IV al trono francés y el apoyo de Felipe II a la Liga Católica brindaban al sultán Murad III la oportunidad de redefinir sus relaciones con los estados del Occidente cristiano. Al principio de la década de los ochenta la Sublime Puerta había sido testigo de cómo Portugal, después de una crisis de sucesión, llegó a formar parte de la Monarquía hispana, perjudicando los intereses otomanos en el Océano Índico ${ }^{4}$. Asimismo, el comienzo de la década de 1590 se inicia con la crisis de sucesión en Francia, suceso que podía perjudicar de manera intolerable la estrategia de los otomanos en el Mediterráneo. Murad III no podía permitir que Felipe II situara a Francia bajo su control, al igual que el Rey Prudente no podía aceptar que fuera un protestante el rey del país vecino. La expiración de la vigencia de la tregua turco-española, y los esfuerzos de Felipe II para renovarla, provocan unos meses de continuas relaciones y de inestabilidad entre los dos imperios. La negativa otomana a la propuesta hispana de renovar la tregua estaba relacionada con la situación de Francia y con la certidumbre de varios de los consejeros del Sultán de que el rey español se había aprovechado de la tregua para incorporar Portugal a sus dominios.

De esta manera, la inestabilidad en Francia se convirtió en el foco de atención para la política exterior turca. Nuevamente el Imperio Otomano fue un elemento más en la coalición de la beligerancia internacional anti-española en esta fase decisiva para la hegemonía en Europa. Las tensiones de Poniente se trasladan al Levante, de tal manera que Estambul es otro foco de la lucha político-confesional europea, factor en el que influye decisivamente la política oriental de Isabel I de Inglaterra ${ }^{5}$. Los agentes ingleses se aliaron desde un primer momento con el bando de Enrique de Navarra en Estambul y explora-

${ }^{3}$ FODOR, 2000: 171-190.

${ }^{4}$ Para la perspectiva otomana sobre el encuentro turco-portugués en el Océano Índico, son imprescindibles los trabajos de Salih Özbaran. ÖZBARAN, 1994.

${ }_{5}^{5}$ El ambiente de la renovación de la tregua con España ha sido estudiado por RODRÍGUEZ SALGADO, 2004. Sobre las relaciones turco-inglesas, véase SKILLITER, 1977. KURAT, 1953. 
ron continuamente la posibilidad de animar una acción naval otomana contra los intereses españoles en el Mediterráneo ${ }^{6}$.

El rumbo de los acontecimientos de las guerras entre Enrique IV y la Liga Católica supuso la división de la antigua política oriental francesa, ya que el vacío en la corona de San Luis dejaba sin cabeza las relaciones francootomanas, además de que los dos contendientes a la corona francesa tenían intereses divergentes en cuanto a sus expectativas con respecto al Sultán ${ }^{7}$. En estos meses el Diván prestaba una extraordinaria atención a los acontecimientos en Francia, noticias que son facilitadas de manera insistente por el embajador inglés, Edward Barton ${ }^{8}$. Se tomaba el pulso de la guerra civil reclamando noticias por todos los medios posibles, situación que es aprovechada por los partidarios de Enrique de Navarra para trasladar su visión de los acontecimientos, lo que genera una verdadera guerra de propaganda anti-Liga y anti-española junto a las orillas del Bósforo9. Este factor provocó que se precipitaran las discusiones en la Corte otomana sobre una nueva política naval, así como las intenciones de reavivar la antigua alianza franco-otomana en el marco de la lucha entre el Imperio otomano y la Monarquía hispana en el mar. El informe del gran visir al sultán Murad III demuestra una de las primeras reacciones del gobierno otomano a esta nueva amenaza a sus intereses geoestratégicos:

El Capitán General mandó a Su Realeza un informe sobre los asuntos de España y Francia...Mi Sublime Sultán, como escribió el Capitán General, es verdad que Francia ha entrado en un caos absoluto y existe la posibilidad de que la maldita España la invada. Las noticias no son desconocidas para mí. Es muy conveniente que se provean las necesidades del Arsenal a su debido tiempo...Mi Sublime Sultán, estoy haciendo esta solicitud para que no se me pregunte después porqué no he preparado la armada si en el país del infiel susodicho [Francia] ocurre una anarquía repentina ${ }^{10}$.

${ }^{6}$ PODEA, 1938, II: 423-476. NIEDERKORN, 1993: 105-128 y 138-151.

7 LESURE, 1986: 37-57.

8 «Que allí se tenía gran atención a las cosas de Francia siendo pocos los que se alegran de los prósperos successos de la Unión Catholica, de que sin embargo de los malos officios del agente inglés al fin se tiene allá noticia», De Constantinopla, 15 y 16 de septiembre de 1590, AGS, Estado, legajo K1674, n. 172.

9 «Que de pocos días á aquella parte los herejes que allí assisten no braveavan como solían de los progresos del Príncipe de Bearne, de que se hazía conjectura que las cosas de los cathólicos estavan en mejor situación que ellos havían publicado», De Constantinopla, 8 y 9 de diciembre de 1590, AGS, Estado, legajo K1675, n. 7; «Que el agente de Inglaterra y otros malos christianos queriendo apoyar como suelen las cosas del Príncipe de Bearne de nuevo havían publicado que se hallava todavía señor de la campaña y de los más importantes lugares del contorno de París, y dispuesto para benir a batalla», De Constantinopla, 22 de diciembre de 1590, AGS, Estado, legajo K1674, n. 188.

10 SAHILLLIOĞLU, 2004: 4-5, doc. 3. 
«GUERRAS DE RELIGIÓN» EN ESTAMBUL: LA POLÍTICA ANTIESPAÑOLA Y LA CRISIS DE LA EMBAJADA FRANCESA

Después de la muerte de Enrique III las relaciones franco-otomanas experimentaron un interesante episodio de crisis en su representación diplomática en Levante. En el fondo, es una demostración más del caos francés por la existencia de diplomáticos que apoyan a los diferentes bandos en litigio. Jacques Savary de Lancosme, embajador en Estambul desde 1586, era un declarado seguidor de la Liga Católica y partidario del pretendiente católico al trono de San Luis. La crisis de la sucesión puso su misión en una situación muy compleja, ya que no reconoció la legitimidad de Enrique IV y luchó para evitar el reconocimiento otomano de un rey protestante en la corona francesa. En un momento en que el futuro Enrique IV solicitaba la ayuda otomana para contener la presión de Felipe II, el embajador procuró llevar a cabo una política a favor de los intereses de la Liga Católica y la Monarquía Hispana en la capital otomana. Aunque en ocasiones se pudo aliar con los elementos habsburgicos residentes en Estambul, Lancosme tuvo que enfrentarse por sí solo al bloque formado por ingleses, franceses navarristas $\mathrm{y}$ otomanos antiespañoles ${ }^{11}$.

Desde la perspectiva de las relaciones franco-españolas, se ha señalado que los propagandistas de Enrique IV acusaban a los miembros de la Liga Católica de ser 'hispanofilias' y 'españolizantes'12, así como la visión providencial de la figura de Felipe II entre ciertos sectores de franceses católicos y la «necesidad de la alianza con el rey de España» para salvar la corona francesa $^{13}$. Las cartas de Lancosme que se conservan en el Archivo General de Simancas demuestran que estas características de las guerras de religión en Francia se reprodujeron también en Estambul. El embajador francés mantenía correspondencia con el Commandeur de Dieu, el representante de la Liga Católica en Roma, y este último compartía todas estas cartas con el conde de Olivares, embajador español en la ciudad. Desde Roma, el diplomático las enviaba al conde de Miranda, virrey de Nápoles, encargado de la red de información en Levante. Olivares, por el complicado ambiente que detectaba en Estambul, decidió remitirlas directamente a Madrid ${ }^{14}$. La calidad informativa de sus cartas impresionaron a los ministros españoles como Francisco de Idiáquez o Francisco de Vera y Aragón, que consideraban a Lancosme un

${ }^{11}$ RIGAULT, 16 (Paris, 1902): 522-578.

12 RUIZ IBÀNEZ, 1998: 147-148.

13 RUIZ IBÁÑEZ, 2004: 33-34.

${ }^{14}$ El conde de Olivares a Felipe II, Roma, 19 de agosto de 1590, AGS, Estado, legajo 956, s. fol. 
informante mucho mejor que el resto de los espías españoles ${ }^{15}$. El conde de Olivares y su sucesor, el duque de Sessa, remitieron a Madrid las peticiones de los representantes de la Liga Católica para que Felipe II mandara alguna ayuda económica a Lancosme para el bien de la Liga como de España ${ }^{16}$.

Lancosme muestra su firme creencia en que el apoyo que Felipe II daba a la defensa de la catolicidad universal ayudaría a solucionar el problema de Francia ${ }^{17}$. Ruiz Ibáñez señala que aquellos franceses que tenían simpatía hacia el Rey Católico lo hacían «simplemente en contraposición a los herejes, pero sin mayor aspiración, ni proyecto de subordinación» ${ }^{18}$. Esto es evidente en las palabras de Lancosme cuando escribió «la mia affettione non ha havuto altro fondamento che dalla cognitione di tanti obligationi che sempre mai havera la corona di Francia alla bonta di Sua Mta» ${ }^{19}$. No obstante, sus esfuerzos a favor de la causa de los agentes de Felipe II en Estambul eran la puesta en práctica de su creencia en la amistad de la Corona de Francia con el Rey Católico, lo que al final fue la razón de su expulsión de la capital otomana ${ }^{20}$.

Enrique IV, ante la falta de un representante propio reconocido por la Sublime Puerta, encargó la defensa de sus intereses al embajador francés en Venecia, Hurault de Maisse, quien, como bearnés, se concertó con Edward Barton, embajador inglés en Estambul. Además, François Savary de Brèves, un pariente próximo de Lancosme, que trabajaba en la embajada francesa de Estambul, se declaró como navarrista acérrimo, aspirando a ser el próximo embajador francés, y junto al delegado inglés se ocuparon de forzar la dimisión de Lancosme ${ }^{21}$.

Así, dos grupos de franceses entraban en la agenda de la política exterior otomana. El primero basaba sus esperanzas en las victorias de la Liga Católica y el segundo estaba formado por los seguidores de Enrique IV. La desunión entre los dirigentes políticos del país galo no sólo generó una enorme confusión en la diplomacia oriental de la corona francesa, sino que también causó una cierta indecisión de los otomanos en el mantenimiento de la amistad tur-

${ }^{15}$ El conde de Olivares a Felipe II, Roma, 25 de febrero de 1591, AGS, Estado, 957, s. fol; Francisco de Vera a Felipe II, Venecia, 20 de junio de 1592, AGS, E, K1675, n. 154.

${ }^{16}$ El conde de Olivares a Felipe II, Roma, 17 de abril de 1591, AGS, E, 957, s. fol; El duque de Sessa a Felipe II, 14 de marzo de 1592, AGS, E, 959, s. fol.

${ }^{17}$ Lancosme al Comendador de Dieu, Constantinopla, 20 de diciembre de 1591, AGS, E, 959, s. fol; Lancosme al Comendador de Dieu, Constantinopla, 10 de julio de 1592, AGS, E, 960, s. fol.

18 RUIZ IBÁÑEZ, 2004: 35.

${ }^{19}$ Lancosme al Comendador de Dieu, Constantinopla, 14 de diciembre de 1591, AGS, E, 959, s. fol.

${ }^{20}$ Lancosme al Comendador de Dieu, Constantinopla, 14 de diciembre de 1591, AGS, E, 959, s. fol.

${ }^{21}$ RIGAULT, 16 (Paris, 1902): 531-550. 
co-francesa. De hecho, el Sultán recibió en un lapso de tiempo muy corto dos cartas oficiales de Francia de sesgo contrario, siendo la primera de parte de Enrique IV, en julio 1590, y la segunda de parte del duque de Mayena, en abril $1591^{22}$. El argumento común de las dos misivas era presentar ante el Sultán la ilegitimidad de su contrincante para la corona francesa y reivindicarse como legítimos herederos de la amistad tradicional entre los reyes franceses y sultanes otomanos. Sin embargo, mientras que Enrique IV pedía la intervención de los otomanos a su favor, lo que demandaba el duque de Mayena era su neutralidad. Lancosme, se hizo el defensor de facto de los intereses de la Liga Católica, aunque en realidad tanto la Liga como Enrique IV se reivindicaban como los verdaderos defensores de la corona francesa.

Al final, el sultán remitió a Enrique IV su reconocimiento como rey de Francia, lo cual, según Lesure, en ausencia de un reconocimiento ceremonial, fue un gesto que nunca se había hecho por un sultán otomano a ningún príncipe cristiano ${ }^{23}$. Desde entonces, las expectativas de Lancosme y la Liga Católica tendieron a ser mucho menores. A principios de 1592 Ruggero Marliani, agente de Felipe II, había avanzado en las negociaciones de tregua con el Sultán que el Rey Católico procuraba desde 1589. La coincidencia de la actuación diplomática del duque de Mayena y la de Felipe II con el fin de neutralizar al Sultán y alejar la posibilidad de una ayuda otomana a Enrique IV dio a los elementos antiespañoles en Estambul la posibilidad de impedir los planes del Rey Prudente. Los ingleses y los navarristas contaban con un considerable apoyo local en la capital otomana. El navarrista De Breves estaba rodeado de un grupo formado por algunos turcos que había rescatado en Malta y estimulaba la opinión pública contra los españoles con la ayuda de los eminentes predicadores de Estambul, sobre todo del vaiz (predicador) de la prestigiosa mezquita de Sultán Solimán ${ }^{24}$. Barton también desempeñaba un papel importante en la formación de la opinión de los altos dignatarios otomanos, como Hoca Sadeddin, el preceptor del Sultán ${ }^{25}$. Aunque el factor decisivo fue que el gobernante turco no encontró una respuesta positiva y rápida a su reiteración para formalizar las negociaciones de tregua y el preceptivo

${ }^{22}$ Copia de carta del Turco a Henrico, Constantinopla, 17 de julio de 1590, AGS, E, 1157, n. 99; El duque de Mayena al Gran Visir, Soissons, 28 de diciembre de 1590; El duque de Mayena al Sultán, Soissons, 28 de diciembre de 1590. Las cartas se encuentran en CSPV, vol. 8, n. 1045-1046.

${ }^{23}$ LESURE, 1986: 55.

24 «venuto a mi il Brevi [De Breves] mi ha detto di volar adoperarsi un pridicator della Moschia di Sultan Suleiman», Mateo Zane al Senado de Venecia, 30 de mayo de 1592, ASVe, SDC, 35, fol. 297r.

25 «The Sultan's secretary [Hoca Sadeddin], a prudent and estimable man, with whom the English Ambassador takes council in all his affairs», Lorenzo Bernardo y Mateo Zane al Dogo y Senado, Constantinopla, 24 de enero de 1592, CSPV, vol. 9, n.12. 
reconocimiento público de la autoridad del príncipe otomano por parte de Felipe II ${ }^{26}$.

En este contexto, se desencadenaron en Estambul una serie de acontecimientos que perjudicaron los intereses de Felipe II, tanto en Oriente como en Francia. Un renegado francés, el Barón de la Fage, reveló los nombres de varios personajes que trabajaban como espías para el Rey Católico ${ }^{27}$. Según Abel Rigault, éste fue enviado a Estambul por el embajador de Enrique IV en Venecia con el fin de sabotear las negociaciones de tregua y reducir la influencia de Lancosme en el Diván ${ }^{28}$. Los otomanos detuvieron a las personas denunciadas, lo que fue un golpe importante a la red de información de Felipe II. Los ingleses y los 'bearneses' aumentaron la presión sobre Lancosme, logrando su encarcelamiento en junio de 1592 bajo la acusación de espionaje y de ser financiado con el dinero del Rey Católico y el $\mathrm{Papa}^{29}$. A finales de este año, la mision de Marliani no encontró la coyuntura favorable para su continuación y se rompieron definitivamente las negociaciones por orden estricta del Sultán. En el mismo momento, la misión de Lancosme también culminó, saliendo el último embajador de los Valois de Estambul al ser expulsado con destino a Francia para que se entregara a Enrique IV. Sin embargo, la armada del conde de Olivares, virrey de Sicilia, bloquearon el pasaje de las galeras que le llevaban y le salvaron de la segura prisión en los primeros meses de $1593^{30}$.

Por un lado estos acontecimientos fueron la consecuencia de la hábil política de los representantes de Enrique IV y Isabel I que supieron convertir los sentimientos antiespañoles, tanto populares como oficiales, en una medida concreta del gobierno otomano en el contexto de su política internacional. Por otro lado, representan un revés de las pretensiones universalistas de la Monarquía Hispánica. La consecuencia más evidente de estos episodios de intrigas diplomáticas ante los altos dignatarios otomanos es que la Sublime Puerta apuesta decididamente por uno de los bandos de las guerras religiosas en Francia, fijando su política exterior de manera nítida.

${ }^{26}$ Mateo Zane al Senado de Venecia, Constantinopla, 22 de marzo de 1592, ASVe, SDC, 35, fol. 53.

${ }^{27}$ De Constantinopla, 18-19 de abril de 1592, AGS, E, 1542, n. 138.

28 RIGAULT, 16 (Paris, 1902): 554.

${ }^{29}$ Mateo Zane al Dogo y Senado, Constantinopla, 11 de mayo de 1592, CSPV, vol. 9, n. 67 , p. 27

${ }^{30}$ El conde de Olivares a Felipe II, Palermo, 4 de abril de 1593, AGS, E, 1157, n. 154. 


\section{LA POLÍTICA DE ENTRETENIMIENTO Y LAS ILUSIONES DE ENRIQUE IV HASTA LA PAZ DE VERVINS}

Enrique IV logró en Estambul una victoria diplomática estratégica contra Felipe II. Desplat afirma que la expectativa de Enrique IV de una empresa naval otomana contra los españoles estaba en su apogeo en $1593^{31}$. El elemento esencial de la apertura de un frente naval antiespañol era cuidar el mantenimiento de la paz entre Venecia y el Sultán. De esta manera se contrarrestaban los intentos de conformar una Santa Liga por parte del papa Clemente VIII para ayudar a Rodolfo II en su guerra contra el Sultán por el control de Hungría ${ }^{32}$. La posible participación de Venecia en una Santa Liga, encabezada por los españoles, habría servido a los intereses hegemónicos de Felipe II y fortalecido la Liga Católica en Francia. La misión de De Brèves, ya embajador de Enrique IV en Estambul, era cooperar con el embajador veneciano con el objetivo de evitar el aumento de la tensión entre el Sultán y la Serenísima ${ }^{33}$. Esta política suponía enfrentarse al Papa, ya que Francia buscaba la repetición de las campañas navales franco-turcas de $1543-1544^{34}$ y $1552^{35}$. Clemente VIII, por el contrario, anhelaba igualarse a Pío V al encabezar un segundo Lepanto.

En la última década del siglo XVI la república de Venecia procuraba que Francia hiciera otra vez sentir, en palabras de Gino Benzoni, «tutto il suo peso riequilibratore in un'Europa troppo sbilanciata a vantaggio della monarchia ispanica ${ }^{36}$. Stefano Andretta afirma la existencia de un importante apoyo a Enrique IV entre el patriciado veneciano, que veían en él la vuelta del contrapeso natural a la amenaza de una posible hispanización de toda Italia ${ }^{37}$. Esta es precisamente la razón de que los embajadores venecianos procuraran fomentar la influencia de Enrique IV y facilitar la correspondencia de sus seguidores en Estambul ${ }^{38}$. De hecho, es muy significativo el comportamiento con Lippomano, bailo en Estambul, a quien la República destituyó repentinamente, y probablemente ejecutó en 1591 por haberse relacionado con las autoridades españolas más allá de lo lícito ${ }^{39}$. El mantenimiento de la amistad con el Sultán era primordial, y no se rompería siempre que los otomanos no perjudicaran los intereses venecianos en Levante y en el Adriático. Las pro-

\footnotetext{
31 DESPLAT, 1990: 407.

32 BORROMEO, 1994: 119-233.

33 Henri IV a De Breves, Saint-Denys, 8 de agosto de 1593, en XIVREY, 1846, vol. 4: 8.

34 ISOM-VERHAAREN, 30/3 (Durham, 2007): 395-425.

35 VEINSTEIN, 39 (Aix-en-Provence, 1985): 35-67.

36 BENZONI, 1973: 27-28.

37 ANDRETTA, 2000: 99.

38 Avisos de Juan Segui, Constantinopla, 22 de febrero de 1592, AGS, E, 1093, n. 20.

${ }^{39}$ GULLINO, 1981, 65: 241-242.
} 
puestas para formar un nueva Santa Liga podían ser contrarrestadas por medio de una diplomacia prudente, dejando siempre entreabierta la posibilidad de apoyarla si la política naval otomana se volvía contra los intereses de la Serenísima.

En cambio, los otomanos quisieron asegurarse de las posiciones de Francia y de Venecia, dos de sus ejes esenciales en la fijación de su política exterior, en relación a su papel en la larga Guerra de Hungría. La noticia de la conversión de Enrique IV al catolicismo suscitó en la Corte otomana los temores de un preludio de rapprochement entre Monarquía hispana y Francia ${ }^{40}$. Enrique IV y su embajador tuvieron que convencer al Sultán de que la conversión era un simple recurso para asegurar la estabilidad del Reino y prevenir, de esta manera, la aspiración del Rey Católico de incorporar Francia a sus dominios $^{41}$. La preocupación esencial de los otomanos era solventar la ambigüedad de la política veneciana, ya que se recibían informes de que apoyaba secretamente al Emperador, así como la formación de una Liga anti-otomana. Los bailos venecianos tuvieron que realizar grandes esfuerzos y entregar grandes sumas de dinero para lograr el apoyo del sector más pro-veneciano del Diván para evitar la escalada de la tensión.

En este contexto, la armada otomana amplió el alcance de su tradicional navegación durante el verano hasta las costas italianas en los últimos dos años de mandato del sultán Murad III. La intención del gobernante no era solo usar la armada como una fuerza disuasoria contra lo que pudiera intentar Felipe II, sino también como una amenaza de intervención directa en función de la evolución de los sucesos europeos. A principios de 1594 hubo un acalorado debate en la cúpula del poder otomano sobre mantener al Adriático fuera de los objetivos de las galeras turcas para castigar a Venecia por las fundadas sospechas de su ayuda a los imperiales a través de este mar. La incursión de una armada extranjera en su Golfo era un casus belli para las autoridades venecianas $^{42}$. Se intercambiaron entre el Sultán y el Dogo amenazas implícitas, en las que ambos dignatarios recordaban la potencial capacidad de cada uno de ellos de producir perjuicios al adversario, corroborada históricamente en los sucesos de Chipre y Lepanto. Cigala, almirante otomano de origen italiano, era tendente a llevar a cabo una política claramente contraria a Venecia y a Enrique IV, ya que tenía una auténtica obsesión en entrar en el Adriático con la armada otomana. Aunque Murad III no permitió que Cigala realizara una acción que podría acabar con la neutralidad de Venecia, los planes del almirante generaron una enorme tensión a lo largo del otoño de 1594, obligando a

40 LESURE, 1986: 57.

${ }^{41}$ Mateo Zane al Senado de Venecia, Constantinopla, 26 de octubre de 1593, ASVe, SDC, 38, fol. 122r.

42 CESSI, 5 (Bari, 1952): 241. 
la República a movilizar su armada hacia la boca del Adriático y revisar la viabilidad de formar parte de la Santa Liga. El Mediterráneo experimentó grandes momentos de tensión, inéditos desde Lepanto, con las principales armadas (otomana, veneciana y española) preparadas para enfrentarse, situación en la que no era ajena la figura de Enrique IV ${ }^{43}$.

Sin embargo, la política exterior del Imperio otomano estaba lo suficientemente centralizada como para no permitir que las semiautónomas acciones de sus ministros provocaran un quebranto innecesario al equilibrio de poderes. En el agitado contexto de 1594 se produjo el famoso y relativamente ignorado ataque de la armada otomana a la ciudad de Reggio di Calabria, puerto estratégico del reino de Nápoles. El historiador francés Claude Michaud se preguntaba si este ataque era el resultado de los esfuerzos de la diplomacia francesa en Estambul o bien una simple acción de corso $^{44}$. Niederkorn afirma que este asalto fue de alguna manera el testimonio de la eficacia de la actuación del embajador francés ${ }^{45}$. En realidad, solo sabemos, del testimonio del embajador veneciano, que los esfuerzos del embajador francés fueron provechosos para convencer al Sultán de no romper la paz entre los venecianos y otomanos $^{46}$. De esta manera, el consecuente asalto improvisado de Cigala en Calabria cerró las esperanzas del Papa de utilizar una posible escaramuza turcoveneta como una chispa para emular un segundo Lepanto ${ }^{47}$. No obstante, este ataque no era suficiente para los intereses franceses, ya que Enrique IV esperaba un asalto más efectivo en las costas de la Corona de Aragón, y su no realización provocaba sucesivas quejas sobre la actitud del almirante otomano, a quien se tildaba como «nemico della natione francese et della fattione navarrista ${ }^{48}$

La sustitución de Murad III por Mehmed III, en enero de 1595, generó nuevas esperanzas para la política oriental de Enrique IV, quien acababa de entrar en guerra abierta contra Felipe II. En septiembre del mismo año se produjo su absolución formal por Clemente VIII, que deseaba que el rey galo se comprometiera en una guerra anti-turca en vez de desgastar su potencial bélico contra España. Sin embargo, Enrique IV no podía permitirse en la situación político-militar de Francia una ruptura de su alianza con el Imperio Otomano, por muy decepcionante que hubiese resultado hasta entonces ${ }^{49}$. De

43 TÜRKÇELIK, 2012.

${ }^{44}$ MICHAUD, 2003: 453, n. 4.

${ }^{45}$ NIEDERKORN, 1993: 108.

46 Marco Venier al Senado de Venecia, Constantinopla, 4 de mayo de 1594, ASVe, SDC, 39, fol. 239r.

${ }^{47}$ Duque de Sessa a Francisco de Vera, Roma, 6 de agosto de 1594, AGS, E, 1544, n. 69.

${ }_{48}$ Mateo Zane al Senado de Venecia, Constantinopla, 3 de agosto de 1593, ASVe, SDC, 37, fol. 510r.

49 DESPLAT, 1990: 412. 
hecho, en las instrucciones que había dado a sus negociadores con el Papa, Enrique IV advertía explícitamente sobre preservar su libertad de acción con sus aliados de religión contraria, especialmente con los turcos, y justificaba su deseo de seguir la amistad turco-francesa con el argumento de que su mantenimiento era simplemente la conservación de la política dinástica que habían practicado sus predecesores Valois ${ }^{50}$. Desde su coronación hasta la paz de Vervins, la actitud diplomática de Enrique IV hacia los otomanos se dividió entre las repetidas ofertas de fiel alianza y la presión de hacer la paz con sus enemigos $^{51}$. Conocía el temor otomano a que una paz con Felipe II permitiera a los españoles socorrer eficazmente Hungría y posibilitara que el Papa organizara a los príncipes cristianos en una Santa Liga ${ }^{52}$. Como señala Niederkorn, la posición interior e internacional de Enrique IV había mejorado con su absolución ${ }^{53}$. Por lo tanto, se encontraba suficientemente capacitado para jugar entre dos políticas y lanzar amenazas tácticas al Sultán. Desplat afirma que el rey francés aumentó, desde principios de 1596, sus presiones sobre la salida de la armada otomana, no sólo para consolidar su control en Marsella sino también para realizar un plan grandioso de atacar simultáneamente con el conde de Essex el sur de España ${ }^{54}$. El arma más fuerte de que disponía Enrique IV para presionar a los otomanos era hacer saber a la Sublime Puerta las presiones recibidas desde Roma para aceptar la oferta papal de una conciliación con Felipe $\mathrm{II}^{55}$.

La reacción inmediata de los otomanos a esta presión fue explorar las posibilidades de su alianza con Inglaterra. A diferencia de la política francesa, la reina de Inglaterra no estaba interesada en la continuación de la guerra turcoimperial, por lo que ofreció su mediación para la paz en Centroeuropa con la perspectiva de que el Sultán concentraría sus esfuerzos contra España en el Mediterráneo. Aunque una armada otomana sin las restricciones de una guerra terrestre podría ser beneficiosa para sus intereses, Enrique IV mantenía una oposición firme a esta paz por varios motivos: el Emperador podría convertirse en una amenaza al ayudar a su tío Felipe II; la Monarquía hispana podría ser incluida en la paz concertada entre el Sultán y el Emperador; o simplemente por su oposición tradicional a la Casa de Austria ${ }^{56}$. La conversión de Enrique IV provocó la desconfianza de Isabel I, quien empezó a bus-

50 Instrucciones de 5 de mayo de 1595, citado en MICHAUD, 2003: 453.

${ }^{51}$ DESPLAT, 1990: 412-413.

52 MICHAUD, 2003: 453.

53 NIEDERKORN, 1993: 150.

${ }^{54}$ DESPLAT, 1990: 410 y 413; Enrique IV a De Brèves, La Fere, 22 de mayo de 1596, en XIVREY, 1846, vol. 4: 588.

${ }^{55}$ MICHAUD, 2003: 453.; Desplat, 1990: 413; NIEDERKORN, 1993: 149.

56 NIEDERKORN, 1993: 150. 
car una posible pacificación de su conflicto con Felipe II. El medio al que recurrió la reina inglesa fue volver a ofrecer su influencia diplomática en la corte otomana para mediar entre el Emperador y el Sultán, con la condición de que el Emperador persuadiera a Felipe II para que renunciase a sus agresiones contra Inglaterra ${ }^{57}$. Pero esta reorientación en la política exterior isabelina no fue fructífera al no aceptar Rodolfo II la mediación inglesa ${ }^{58}$.

En una carta del Sultán a la reina inglesa se puede observar cómo la estrategia de Mehmed III se basaba en verificar los rumores a través de Inglaterra, su otro aliado, y así comprobar la verdadera situación con respecto a Marsella y a la sospechada paz franco-española. La carta tantea sutilmente la actitud inglesa ante la posible salida de Francia de la alianza entre los tres, además de que tiene el objetivo de conservar con buenas promesas la alianza inglesa:

Que se escriba carta imperial a la Reina de Inglaterra: Vuestro embajador que se encuentra en nuestra Puerta de Felicidad nos avisó que algunos reyes, a través de su mediación, deseaban hacer paz entre el Rey de España y el Rey de Francia, por lo que, había posibilidad de que la paz entre dichos reyes causara un total daño a Vosotros. Dado que no doy mi consentimiento imperial a que alcancen daños a Vosotros y vuestras tierras, han salido mis órdenes imperiales para proporcionar asistencia y protección en concordancia con la amistad antigua y las capitulaciones. De acuerdo con los términos de la fidelidad, como en los antiguos tiempos, soy amigo de vuestros amigos y enemigo de vuestros enemigos. Si es verdadero el aviso que recibisteis sobre el Rey de Francia y el de España, que se me avise inmediatamente. Con el permiso de Alá, nuestra intención es sacar en la primavera mi gran armada imperial para proteger mis tierras y realizar conquistas grandes. Asimismo, vuestro embajador ha avisado que la ciudad de Marsella en la provincia de Francia es subordinada al Rey de España. Y me ha pedido que mi armada imperial vaya a Marsella, se la arrebate de las manos del Rey de España y la entregue al Rey de Francia de acuerdo con las costumbres antiguas. Por tanto, he dado órdenes de que nuestra armada vaya hacia Marsella. Es decir, si es verdad que ellos [Marsella] se han sometido al Rey de España, nuestra armada tiene órdenes de advertirles y entregar la ciudad al Rey de Francia; si no son sometidos al Rey de España sino al de Francia como en los antiguos tiempos, nuestra armada les dejará en paz. Que investiguéis esta situación y que me aviséis en qué consiste la situación de Marsella y también si es verdadero o no el deseo de los reyes de España y Francia para concertar una paz entre si $^{59}$.

Los otomanos ya conocían la necesidad de ejercer una fuerte presión sobre los habitantes de Marsella para que trocaran su lealtad al bando de Enrique $\mathrm{IV}^{60}$. En esto radicaba la seguridad de las posesiones otomanas en el norte de

57 WERNHAM, 1994: 3.

58 WERNHAM, 1994: 10-11.

59 BOA, Bâb-1 Âsafî, Mühimme Defteri, n. 934, 23/14, 5 de junio de 1596.

${ }^{60}$ JENSEN, De Lamar, 16/ 4 (Missouri, 1985): 469. 
África, porque si Provenza caía en manos de Felipe II se podría convertir en una base marítima peligrosa. Aunque había recuperado Marsella en febrero de 1596, Enrique IV siguió con continuadas solicitudes para que el Sultán realizara una estratégica intervención en el puerto provenzal para poner fin a la amenaza española ${ }^{61}$. Sin embargo, como los otomanos nunca atendieron debidamente a las peticiones francesas, tampoco hicieron caso a estas solicitudes en los primeros años del reinado de Mehmed III. El nuevo Sultán necesitaba una victoria contra el Emperador para consolidar su autoridad, y por lo tanto, canalizaba su maquinaria bélica al frente terrestre. A pesar de que el embajador de Enrique IV tenía mejor relación con el nuevo almirante, Halil Pasha, que con Cigala, al que acusaba de ser anti-francés ${ }^{62}$, la política mediterránea de Mehmed III tuvo un sesgo defensivo a principios de su reinado.

Las ordenes de Mehmed III a sus ministros respecto a la guerra en Francia son claras para entender sus verdaderas intenciones. El Sultán advirtió al gobernador, al kadi y a la milicia de Argel que no se impidiera el abastecimiento que los franceses necesitaban de Argel porque «están luchando contra el Rey de España» ${ }^{63}$. En una orden a Halil Pasha, su nuevo almirante, Mehmed III le ordenaba que usara su autoridad para castigar a los gobernadores que violaban las capitulaciones comerciales entre el rey de Francia y el Sultán ${ }^{64}$. Es decir, en vez de enviar órdenes con un contenido que encajara con lo prometido a Inglaterra o a Francia, se limitaba a proporcionar un contexto que favoreciera a Francia en su guerra contra España. En consecuencia, la promesa otomana de extender el alcance operativo de la armada hasta Marsella era una maniobra retórica turca para conservar su reputación. No obstante, la protección declarada por el Sultán al rey francés convertía al Imperio otomano en socio implícito del tratado de Greenwich, firmado en mayo de 1596 entre Francia, Inglaterra y los rebeldes holandeses, cuya condición principal era no concluir una tregua separada con Felipe $\mathrm{II}^{65}$.

De todos modos, 1596 fue un año de ataques significativos contra las dos ramas de los Habsburgo desde dos frentes dispares, lo que podría ofrecer buenas perspectivas para Enrique IV. A finales de junio de 1596 los ingleses tuvieron un gran éxito en el ataque a Cádiz, al mando del almirante Howard y el conde de Essex. En octubre del mismo año, Mehmed III logró una importante victoria terrestre contra los imperiales en Mezőkeresztes. En contraste, la armada otomana, bajo mando del Halil Pasha, ni intervino ese verano en

${ }^{61}$ Enrique IV a De Brèves, Abbeville, 17 de junio de 1596, en XIVREY, 1846, vol. 4: 600; Enrique IV a De Brèves, Amiens, 8 de julio de 1597, en XIVREY, Ibídem: 806.

${ }^{62}$ Enrique IV a De Brèves, Fontainebleau, 27 de abril de 1595, en XIVREY, Ibídem: 345.

${ }^{63}$ BOA, ADVN, Düvel-i Ecnebiye, defter n. 901, 68/8, 10 de junio de 1596.

${ }^{64}$ BOA, ADVN, Düvel-i Ecnebiye, defter n. 901, 69/9, 10 de junio de 1596.

${ }^{65}$ ALLEN, 2001: 36. 
Marsella ni salió más allá del Peloponeso, contrariando las expectativas del rey galo. Aun así, Desplat señala que, a finales de ese año, una parte del plan de Enrique IV parecía estar en proceso de triunfar por el fracaso del ejército del Emperador. Sin embargo, al rey galo se le notaba cierto cinismo al interpretar la situación de la Cristiandad ${ }^{66}$. De la misma manera, Sahin-Toth observa, en el siguiente comentario del embajador francés en Estambul sobre la victoria otomana, una significativa muestra de 'doble conciencia' en relación a los conflictivos intereses de la Cristiandad y Francia. De Brèves, mientras transmitía el disgusto por el daño recibido por el Imperio, lo veía a la vez como una ocasión que podría haber incrementado el fastidio de Felipe II si hubiese sido acompañada por un ataque de la armada otomana ${ }^{67}$.

Enrique IV aprovechó esta coyuntura para consolidar una política de alianzas guiada por la razón de Estado, pero poco realista en cuanto a sus peticiones al Sultán. En un ambiente político marcado por la euforia de la victoria otomana, el embajador de Enrique IV tuvo a mediados de enero de 1597 una audiencia con los ministros en el Diván ${ }^{68}$. Según el relato del cronista Selaniki, el embajador propuso un ataque en el que una armada otomana de 100 galeras se juntaría con 30-40 galeras francesas en una fortaleza española habitada por los moriscos. No sabemos exactamente a qué fortaleza se refería el embajador, ya que Selaniki no especifica su nombre. Además, según el cronista, el embajador francés afirmaba que esta fortaleza perteneció anteriormente a Francia y después había sido arrebatada por los españoles. El plan era salvar a los musulmanes del 'cruel' dominio español y entregar la fortaleza a los otomanos, pasando sus habitantes al amparo de la justicia del Sultán, el protector de la religión islámica ${ }^{69}$. Es posible que el cronista hubiese dramatizado el tono del discurso del embajador. Sin embargo, está claro que los franceses no solamente intentaban jugar con los sentimientos anti-españoles de los otomanos sino también conmoverles con ideas de colaboración islámica, con sus correligionarios bajo «yugo cristiano».

No es difícil tener la sensación de que los planes propuestos por Enrique IV o su embajador fueran algo forzados, y que provenían de sobreestimar la potencia otomana y su predisposición. A principios del año 1597, Mehmed III confirmó la renovación de las capitulaciones franco-otomanas, ratificación

${ }^{66}$ Enrique IV al condestable de Francia, Rouen, 15 de noviembre de 1596, citado en DESPLAT, 1990: 410.

${ }^{67}$ De Brèves a Enrique IV y a Villeroy, Constantinopla, 23 de noviembre de 1596, citado en SAHIN-TÓTH, 1997, 1: 162, n. 118.

68 «The French Ambassador has kissed hands and made his presents. He urged the despatch of a fleet». Girolamo Capello y Marco Venier al Dogo y Senado, Constantinopla, 14 de enero de 1596, CSPV, vol. 9, n. 535.

${ }^{69}$ SELANIKI, 1989, II: 657-658. 
que se debía realizar por cada Sultán. Esto era tal vez fruto de la política dual de amistad y presión adoptada por Enrique IV, o de la política de capitulaciones adoptada por los otomanos para condicionar sus alianzas a concesiones comerciales. Sin embargo, no se trataba de un pacto ofensivo o defensivo tradicional, y no refería la tradicional cooperación militar. Al final, la única ayuda recibida por Enrique IV fue el desembarco del famoso corsario argelino Murat Beg en Marsella con sus pocas galeras en el verano de 1597, con el fin de desbloquear Marsella de la amenaza de los españoles ${ }^{70}$.

Las ilusiones de Enrique IV de que los otomanos le ayudarían en sus pretensiones se transformaron en decepción. Los problemas internos del gobierno del Sultán y su tendencia a la paz con el Emperador hacían la política exterior del Imperio Otomano mucho menos previsible ${ }^{71}$. Al mismo tiempo, el rumor de que algunos judíos llevaban cartas de los ministros de la Monarquía Cristobal de Moura y Juan de Idiáquez para abrir negociaciones de tregua entre el Sultán y el Rey Católico redujo las esperanzas de Enrique en lograr la alianza ${ }^{72}$. Ante el riesgo de un inminente cambio en el equilibro de poder, el rey francés recurrió a su poco creativa política oriental: inquietar a los otomanos con la amenaza de la reconciliación con España a través del Papado ${ }^{73}$. De la misma manera, el embajador inglés procuraba desviar la paz con los españoles lanzando el ultimátum de que su Reina también seguiría el ejemplo del Sultán para llegar a un acuerdo con el Rey Católico ${ }^{74}$. Según Desplat, el balance general de la alianza turco-francesa a finales de 1597, en vísperas de la paz de Vervins, era bastante negativo ${ }^{75}$. La advertencia que se recoge en la crónica de Selaniki quizá explicaba el por qué: «se ha dicho que el frecuente incumplimiento de las promesas resulta en discordia y causa la alianza de los enemigos de la religión $\rangle^{76}$.

${ }^{70}$ DESPLAT, 1990: 397; Enrique IV a De Brèves, Amiens, 6 de septiembre de 1597, en XIVREY, 1846, vol. 4: 840 .

${ }^{71}$ SAHIN-TÓTH, 1997: 162; Enrique IV a De Brèves, Amiens, 8 de julio de 1597, en XIVREY, 1846, vol. 4: 805.

72 «Mon ambassadeur qui est en Levant m'a escript par ses dernieres estre nagueres arrivé par dela un juif avec lettres et charges du roy d'Espagne pour traicter avec le Turc une trefve ou une paix». Enrique IV al duque de Piney, Amiens, 30 de noviembre de 1597, en XIVREY, 1846, 4: 883. Más información sobre la negociación de estos judíos se encuentra en NIEDERKORN, 37/4, (Viena, 1995): 863-867.

73 «Sera à propos que vous leur faciés sentir sur ce subject comme je suis, de ce present, recherche d'accord avec le roy d'Espagne par l'entremise du Pape». Enrique IV a De Brèves, Paris, 23 de noviembre de 1597, en XIVREY, 1846, 4: 879; SAHIN-TOTH, 1997: 162.

${ }^{74}$ Girolamo Capello al Dogo y Senado, Constantinopla, 6 de octubre de 1597, CSPV, vol. 9 , n. 622 .

${ }^{75}$ DESPLAT, 1990: 413.

${ }^{76}$ SELANIKİ, 1989, II: 658. 
ENTRE LA RAZÓN DE ESTADO Y POLÍTICA CATÓLICA: RELACIONES FRANCOOTOMANAS BAJO LA VIGILANCIA DEL PAPADO DESPUÉS DE LA PAZ DE VERVINS

Clemente VIII consideraba necesaria la paz en la guerra franco-española como primer paso para cumplir su anhelo de unir a todos los príncipes cristianos en una guerra anti-otomana. Para esto, no solo tenía que convencer a Enrique IV sino también a Felipe II, quien rechazaba reconocer a Enrique como rey de Francia. Sin embargo, el Papa consideraba de suma importancia la consolidación de la autoridad de Enrique IV, no sólo para restablecer el equilibrio entre Francia y España sino también para recuperar la libertad de acción de la Curia romana, la cual había quedado a la sombra de la Monarquía Hispanica la mayor parte de la segunda mitad del siglo XVI. A pesar de la negativa de los predecesores de Clemente VIII a aceptar la pretensión de Enrique IV al trono francés, el nuevo Papa vinculaba los asuntos de Francia con la liga anti-turca, para la cual necesitaba más a Francia que a España. Por su parte, también Enrique IV requería el apoyo del papado para asegurar su posición en Francia. Así, aunque por una parte rechazaba negociar con los representantes papales su política exterior, por otra mostraba su buena voluntad a las peticiones del Papa para participar en una Liga Santa. En este sentido, Enrique IV supo alimentar hábilmente las esperanzas de Clemente VIII de que rápidamente acabarían sus buenas relaciones con el Sultán ${ }^{77}$.

Pero esta confianza papal en la sinceridad de Enrique IV no fue recibida con agrado por los españoles. La instauración del nuevo rey francés y su confirmación por el Papa preparaban el terreno para la pretensión francesa de recuperar su viejo papel de liderazgo en la Cristiandad. Ello suponía minar la posición española al «superar la imagen de una monarquía francesa inferior en lo religioso a la hispánica» y para mostrar que los españoles no podían pretender dirigir a los católicos franceses ${ }^{78}$. En este contexto, la continuación de la alianza turco-francesa reforzaba los argumentos españoles para desacreditar ante el Papa la sinceridad de las promesas de Enrique IV. A pesar de su desaprobación hacia la política oriental del Rey Cristianísimo, Clemente VIII también mostró cierta tolerancia en la creencia de que la paz franco-española cambiaría la actitud de Enrique IV. Una carta del embajador español en Roma, duque de Sessa, puso en evidencia esta estrategia papal a pocos meses de la firma de la paz de Vervins. En octubre de 1597, Sessa relató a Felipe II la conversación que mantuvo con Clemente VIII sobre la correspondencia interceptada de Enrique IV con su embajador en Estambul y Mehmed III. En ella, el rey francés proponía al Sultán un ataque marítimo a las posesiones españo-

77 BORROMEO, 2000: 323-344.

78 RUIZ IBÁÑEZ, 2005: 532 y 536. 
las de Nápoles y Sicilia. El embajador de Felipe II no perdió la oportunidad de denigrar a Enrique IV y ofrecer su visión particular sobre las consecuencias divinas que trajo a la Monarquía francesa su alianza con el Turco:

A propósito de los grandes títulos lisonjas y palabras de amistad y de rogar a Dios que ensalce y prospere la grandeza del Imperio Ottomano que contiene la carta del de Bearne al Turco, la tradución de la qual en italiano me leyó Su Santidad tuve occasión de poder representarle quán vanas promessas son las que el de Bearne le haze sobre romper la guerra al Turco y coligarse con los demás Príncipes de la Christiandad para ello, y que como podía esperarse que Dios huviesse de favorescer a quien conservava tan estrecha amistad con los infieles y hereges y llamava enemigo común a VMd por que en Francia avia defendido y ayudado los buenos cathólicos que reusavan subjetarse a un herege, y se conservan obedientes a esta Sancta Sede y que me maravillava como no acabavan los franceses de caer en la quenta que todo lo que han padescido y padescen, ha sido y es castigo de Dios de aver admitido la amistad del Turco por solo emulación de la corona de España en tiempo que florescía mucho la de Francia en Religión y obediencia a Sus Reyes ${ }^{79}$.

Sin embargo, Clemente VIII no compartía la perspectiva española y su respuesta muestra que la retórica anti-otomana no se debe confundir con el pragmatismo de la diplomacia del siglo XVI ${ }^{80}$. Aunque la defensa del catolicismo es el objetivo final, la disimulación o un cierto enmascaramiento podían ser instrumentos para superar los impedimentos inmediatos para alcanzar una paz entre España y Francia:

Arrasáronsele a Su Santidad los ojos y respondió me que tenía razón, pero que con todo esto no desconfiava de que los tiempos podían mudarse y tomar algún día los franceses las armas contra el Turco, y que lo que importa agora es procurar el effecto de la paz y tornó a dezirme que nadie entendiesse que me avía mostrado esta carta sino Vuestra Magestad y el conde de Olivares ${ }^{81}$.

Como no disgustaba a Clemente VIII el fracaso español en Marsella, quizá tampoco le molestase mucho la amenaza turca instrumentalizada por Enrique IV para contrarrestar la hegemonía española. Es más, se puede interpretar que el Papa pensaba que esto podría facilitar el entendimiento entre las dos monarquías $^{82}$. Por lo tanto, aunque la pérdida de Marsella fue un golpe para Feli-

${ }^{79}$ El duque de Sessa a Felipe II, Roma, 12 de octubre de 1597, AGS, E, 969, n. 139.

${ }^{80}$ Para un análisis de las alianzas con el 'Infiel' en los conflictos inter-europeos, véase ISOM-VERHAAREN, 2011: 1-23.

${ }^{81}$ El duque de Sessa a Felipe II, Roma, 12 de octubre de 1597, AGS, E, 969, n. 139.

82 «Aunque Su Santidad no lo ha mostrado, sospecho que no le deve de aver pesado dello y he entendido de buena parte que con esto ha entrado en esperança de que se facilitara la paz con Vuestra Magestad la qual si Marsella quedara por Vuestra Magestad tenía por dificultosa». El duque de Sessa a Felipe II, Roma, 5 de marzo de 1596, AGS, E, 967, n. 57. 
pe II $^{83}$, en realidad, el hecho de que fuera controlada por Francia impedía una intervención otomana. De la misma manera, una Marsella francesa era preferible por disminuir la presión otomana sobre Occidente y para evitar las alteraciones que su ocupación por los españoles pudiera causar entre los potentados de Italia ${ }^{84}$. Se ha argumentado que aunque los intereses de la Cristiandad eran prioritarios, la política del Papado no estaba exenta de intereses seculares, y las negociaciones de Vervins aseguraron a Roma libertad de acción y preeminencia en Italia. La muestra inmediata fue la incorporación del ducado de Ferrara al Estado de la Iglesia ${ }^{85}$.

Los otomanos, ya en alerta por la caída de Győr (Raab) en marzo de 1598 ante la presión de los imperiales, tuvieron que replantearse su política por el equilibrio de la península italiana, a la que siempre fueron muy sensibles. Visceglia señala que la anexión de Ferrara atribuía una «indiscutible centralidad» a la Santa Sede en la política italiana ${ }^{86}$. Los otomanos se percataron de este aumento del poder del Papa, de cuya potestad espiritual y unificadora sobre los estados católicos habían sido siempre temerosos ${ }^{87}$. Mientras que la negociación franco-española incrementaba la incertidumbre sobre el desarrollo de las relaciones turco-francesas, el acercamiento de los territorios del Papado a los de Venecia significaba un elemento de sospecha en las relaciones véneto-otomanas. Ante la percepción de una desarticulación de las alianzas, el gobierno otomano procuró mantener relaciones más amigables para no quebrar el tradicional equilibrio de poderes. En cuanto a Venecia, Hoca Sadeddin ${ }^{88}$, el preceptor del Sultán y Muftí, era una figura que podía asegurar el mantenimiento de la amistad gracias a la buena consideración que gozaba entre las autoridades venecianas ${ }^{89}$. No obstante, se renovó la autoridad de Cigala como almirante cuyos antecedentes eran suficientes como para mantener a raya, y también desconfiados, a los venecianos. La Señoría, aunque no estaba de ninguna manera interesada, aprovechaba la tendencia a crear en

83 VÁZQUEZ DE PRADA, 2004: 442-443.

84 «Todavía recelava [El Papa] que el apoderarse Vuestra Magestad de Marsella fuesse ocasión de procurar los franceses traer la armada del turco a Tolon como se hizo y causar alteraciones en Italia». El duque de Sessa a Felipe II, Roma, 29 de enero de 1596, AGS, E, 967, n. 31.

${ }^{85}$ RIVERO RODRÍGUEZ, 2005: 419.

86 VISCEGLIA, 2008, vol. 4: 950.

${ }^{87}$ «Essendosi divulgato per aviso di ragusei l'arrivo de Sua Santita in Ferrara, mandó il bassa...desiderava di parlarmi quel giorno medesimo doppo il suo ritorno dal divano». Girolamo Capello al Senado de Venecia, Constantinopla, 27 de junio de 1598, ASVe, SDC, 47, n. 22.

${ }^{88}$ FLEMMING, 1979, vol. 5: 27-28.

89 «...essendosi in ogni tempo dimostrata cortese et affettionata verso quella Serenissima Repubblica, potrà hora maggiormente adoperarsi nel stabilemento della buona amicitia». Girolamo Capello al Senado de Venecia, Constantinopla, 21 de abril de 1598, ASVe, SDC, 47, n. 12. 
Italia una Santa Liga para que se pusiera freno a las actividades de la armada otomana $^{90}$. La conclusión de la paz franco-española aumentó las preocupaciones otomanas de que Francia pudiera formar parte de los proyectos papales de Santa Liga. Sadeddin se dio cuenta aún más de que la coyuntura estaba cambiando, y, de esta manera, confirmar la neutralidad de Venecia fue una constante en sus audiencias con el embajador de la Serenísima, quien recibía del Senado órdenes para no disgustar al gobierno otomano ${ }^{91}$.

Detrás de esta política de estabilidad y de no conflicto con Venecia estaba también Gazanfer Aga, el privado del Sultán. Dada su procedencia veneciana y la autoridad que tenía con Mehmed III, Gazanfer seguía constituyendo, quizá más que Safiye Sultán, madre de Mehmed III, y Hoca Sadeddin, un factor que garantizaba una tranquilidad continúa en las relaciones véneto-otomanas. Es posible que los otomanos no observaran el principio de reciprocidad en su conducta diplomática con sus aliados ${ }^{92}$. Pero eran personajes como Gazanfer quienes conservaban la esencia del Imperio Otomano en el equilibrio europeo. De este modo, es muy significativa la conversación del embajador veneciano con este renegado veneciano. Al pronunciar Gazanfer su «gran travaglio della pace seguita» de los franceses, «amici simulati», el bailo Capello le dice que debía de gloriarse de «la sua Patria tanto amica del Gran Signore» ${ }^{93}$. Por su parte, Venecia procuraba convertir la desconfianza hacia la política francesa expresada por Gazanfer y otros ministros en una ocasión para acrecentar la singularidad de la política de la República con respecto al Sultán. En cuanto a los otomanos, si la alianza con Francia entraba en una fase ambigua, los esfuerzos se canalizarían en fortalecer los lazos con el otro aliado.

La conclusión de la paz de Vervins, sin el previo conocimiento del Sultán, abrió un periodo de relaciones ambiguas y tensas entre Francia y el Imperio Otomano. Sahin-Toth señala que las cartas de Enrique IV justo después de la paz podrían significar un auténtico punto de inflexión en la política oriental del rey francés ${ }^{94}$. De la misma manera, Niederkorn afirma que, si existía la posibilidad de una ruptura entre el Sultán y Enrique IV durante la Larga Guerra, los días siguientes a la paz fueron el primer momento en que se podría

90 «Io credo pero che al Cigalla sará posto il freno con commandamenti efficaci, et che egli disimule per hora perche vorranno questi che egli vadi molto circonspetto per la gelosia che hanno della Serenita Vostra». Girolamo Capello al Senado de Venecia, Constantinopla, 15 de mayo de 1598, ASVe, SDC, 47, n. 16, fol. 138r.

${ }^{91}$ Girolamo Capello al Senado de Venecia, Constantinopla, 27 de junio de 1598, ASVe, SDC, 47, n. 22, fol. 226v.

92 YURDUSEV, 2004: 5-35.

${ }^{93}$ Girolamo Capello al Senado de Venecia, Constantinopla, 25 de julio de 1598, ASVe, SDC, 47, n. 29, fol. 302v; DURSTELER, 2006: 121-127.

94 SAHIN-TÓTH, 1997: 164. 
haber producido ${ }^{95}$. En este sentido, Michaud asegura que tras Vervins se abrió un corto periodo durante el cual Clemente VIII pareció cercano a alcanzar su objetivo de incluir a Francia en una guerra santa ${ }^{96}$. Sin embargo, según Desplat, aunque el tratado de Vervins representaba una fase importante en las relaciones turco-francesas, no modificó profundamente la naturaleza de esa relación porque la paz no había extinguido el odio de Enrique IV hacia España. Por tanto, su política tanto con el Papado como con el Imperio Otomano era «oportunista»y, al mismo tiempo, no dejaba de crear complicaciones para España ${ }^{97}$.

Entre la paz de Vervins y el principio de la crisis de Saluzzo las relaciones franco-turcas pasaron por un periodo tenso y dudoso. Enrique IV se planteó revisar su política oriental y dio la impresión de querer menguar su relación con el Imperio Otomano. Incluso se planteó llamar a su embajador de vuelta a Francia. Aunque no quería recurrir a una opción tan radical como romper la relación con el Sultán, creía que esta alianza le traía más problemas que utilidad, y que no tenía necesidad de intimidar a sus enemigos cristianos con la amenaza de su amistad con el Sultán ${ }^{98}$. Ante el malestar que despertó la pacificación de Francia con España, Enrique IV imputó a los otomanos la responsabilidad de haber llegado a un acuerdo con Felipe II porque no recibió la asistencia prometida contra los españoles, lo que demostraba el poco interés que tenían los ministros otomanos en conservar la relación con Francia ${ }^{99}$.

Este razonamiento contenía, además de un resentimiento, una amenaza implícita. Los otomanos se encontraban seguros en el flanco mediterráneo mientras continuara el conflicto entre las dos monarquías. Como ya no hacía falta que Enrique IV pidiera ayuda al Sultán contra el Rey Católico, las relaciones franco-turcas no iban a evolucionar en función de la amenaza española, como enemigo común, sino en función del respeto que mostrara el gobierno otomano a los intereses y súbditos franceses en Berbería. Enrique IV, ya reconocido como tal por Felipe II, se mostraba más receptivo a las propuestas de Liga y más entusiasta en llevar a cabo misiones dignas de su título de Rey Cristianísimo y en consolidar la posición francesa en la Curia, por la que tantos años había luchado ${ }^{100}$. La amenaza al Turco, en vez de comprometer la posición de Francia para el Imperio Otomano, hacía que los turcos efectuaran

95 NIEDERKORN, 1993: 175-176. SAHIN-TÓTH, 1997: 165.

${ }^{96}$ MICHAUD, 2003: 454.

97 DESPLAT, 1990: 414-416.

${ }^{98}$ Enrique IV a De Brèves, Paris, 13 de junio de 1598, en XIVREY, 1846, 4: 1008. SAHIN-TÓTH, 1997: 164. MICHAUD, 2003: 455.

${ }^{99}$ Enrique IV a De Brèves, Paris, 10 de julio de 1598, en XIVREY, 1850, 5: 5. NIEDERKORN, 1993: 176.

${ }^{100}$ MICHAUD, 2003: 454-455. 
más concesiones, aunque no todos los ministros del Sultán estaban de acuerdo sobre el comportamiento a seguir. Por ejemplo, aunque la corte otomana había conseguido suavizar la mala disposición de Cigala hacia Venecia, como se comprobó en su reunión privada con el almirante veneciano ${ }^{101}$, en raras ocasiones cejó su animadversión contra lo francés ${ }^{102}$.

El gobierno otomano, sobre todo durante el Gran Visirato de Ibrahim Pasha (enero de 1599 a julio de 1601), se dedicó a convencer a Enrique IV de que se remediarían las injusticias cometidas contra los franceses ${ }^{103}$. De hecho, Sahin-Tóth señala que hasta finales de 1599 los otomanos tuvieron la inquietud de una posible ruptura con Francia, dado que Enrique IV pensaba retirar a su embajador, De Brèves ${ }^{104}$. A pesar de que Ibrahim Pasha respondió favorablemente a la petición de retorno del embajador francés, el nuevo Mufti Sunullah Efendi, persuadió al Gran Visir para que no permitiese su vuelta a Francia. Según el Muftí, amigo personal del embajador francés, sería una imprudencia permitir su retirada antes de subsanar, entre otras cosas, el ambiente tenso marcado por el insulto que Cigala había cometido hacia la persona de Enrique IV al retener las cartas del Sultán y su regalo al rey francés ${ }^{105}$.

Sin embargo, las circunstancias cambiaron con el estallido de la guerra de Saluzzo en otoño de 1600, que demostraba la fragilidad de la paz francoespañola. Hasta entonces reinó el triunfalismo en las negociaciones para formar una Liga católica en la que Roma, en cooperación con Felipe III, contemplaba integrar a Rodolfo II y Enrique IV ${ }^{106}$. El optimismo en Francia era tan alto que, según Michaud, el nuncio en París se atrevía a asegurar a finales de 1599 la proximidad de una Liga con participación francesa ${ }^{107}$. De hecho, el embajador veneciano en Estambul señaló que Enrique IV había llamado a su embajador residente ante el Sultán de vuelta a Francia para valerse de sus consejos en caso de participar en una Liga ${ }^{108}$. Enrique IV se desenvolvía con sutileza diplomática, entre mentiras al Sultán y muestras de buena voluntad hacia el Papa. Por un lado, declaraba que abrazaría la Liga anti-turca con la condición de que se organizara como una guerra total que pudiera acabar para siempre con el Imperio Ótomano. Por otro, como tal cosa era muy difícil de realizar, aconsejaba a su

101 Íñigo de Mendoza a Felipe III, Venecia, 19 de diciembre de 1598, AGS, E, K1676, n. 177.

102 NIEDERKORN, 1993: 177-178. SAHIN-TÓTH, 1997: 166.

${ }^{103}$ SAHIN-TÓTH, 1997: 165. Véase, WEIS, 2011.

104 SAHIN-TÓTH, 1997: 165, n. 129.

${ }^{105}$ Girolamo Capello al Dogo y Senado, Constantinopla, 22 de febrero de 1600, CSPV, vol. 9 , n. 857 .

${ }^{106}$ GONZÁLEZ CUERVA, 2009, II: 1149-1186.

107 MICHAUD, 2003: 457.

108 «Sua Maestà [Enrique IV] lo richiamava per valersi del suo consiglio in qualche occasione importante, e parva che tendesse a pensieri di lega, e simili, contra Turchi». «Relazione di Girolamo Cappello (1600)», en PEDANI-FABRIS, Maria Pia (ed.), 1996, vol. 14: 447. 
embajador en Roma que remitiera su buena voluntad al Papa con mucha discreción para que los turcos no se alertasen ${ }^{109}$. Cuando tanto los otomanos como el Papado analizaban con atención hacia donde se decantaba la posición francesa, estalló en agosto de 1600 la crisis de Saluzzo. Esto desvió a Enrique IV de la posibilidad de un giro serio en su política oriental ${ }^{110}$.

La escalada de la tensión entre Francia y España propició las esperanzas otomanas en que se renovaría el conflicto entre el Rey Católico y el Rey Cristianísimo. Según informó De Brèves a Sillery, embajador francés en Roma, los ministros otomanos recibieron con mucho contento los avisos de la guerra entre el duque de Saboya y Enrique IV, y esperaban que Felipe III interviniera en el conflicto ${ }^{111}$. En este contexto, el rey francés volvió a jugar la baza de sus intereses comunes contra los Habsburgo en sus relaciones con el Sultán. Capello afirma que Enrique IV revocó su intención de retirar a su embajador en Estambul por la necesidad que tendría de él allí durante el conflicto ${ }^{112}$. En consonancia, en enero de 1601 le ordenó que animara secretamente a la corte otomana para que el Sultán organizase un ataque contra las costas de Calabria $^{113}$. Según el bailo veneciano, De Brèves procuraba estorbar cualquier ocasión de acuerdo turco-español ${ }^{114}$ y presentaba la guerra de su Rey contra el duque de Saboya como un suceso que evitaría la unión de la Cristiandad, ya que el Rey Católico estaría ocupado en la defensa de su cuñado ${ }^{115}$. El informe que Yemişci Hasan Pasha remitió al Sultán refleja la ilusión que creaba el embajador francés: el rompimiento de la paz entre las Monarquías hispana y francesa desencadenaría una guerra entre ambos soberanos cristianos e imposibilitaría que los príncipes católicos pudieran proporcionar asistencia al emperador Rodolfo II ${ }^{116}$. El Gran Visir Ibrahim Pasha, comandante general en Hungría, procuró aprovecharse de este nuevo ambiente y mandó un emisario a Enrique IV en la primavera de 1601. El objetivo era proponerle una alianza ofensiva contra Felipe III y además solicitar la mediación francesa para llegar

109 MICHAUD, 2003: 457.

${ }^{110}$ DESPLAT, 1990: 397.

${ }^{111}$ De Brèves a Sillery, Constantinopla, 15 de octubre de 1600, citada en SAHIN-TOTH, 1997: 177, n. 167.

112 «Relazione di Girolamo Cappello (1600)», en PEDANI-FABRIS, Maria Pia (ed.), 1996, vol. 14: 447.

113 «L'ambassadeur doit exciter secrètement la Porte attaquer les côtes de la Calabre et de la Sicilie». Resumen de la carta de Enrique IV a De Brèves, Paris, 10 de enero de 1601, en XIVREY, 1850, V: 744. SAHIN-TOTH, 1997: 176, n. 166.

${ }_{114}$ Agostino Nani al Senado de Venecia, Constantinopla, 13 de noviembre de 1600, ASVe, SDC, 52, n. 18, fol. 119r.

115 Agostino Nani al Dogo y Senado, Constantinopla, 20 de febrero de 1601, CSPV, vol. 9, n. 959.

${ }^{116}$ ORHONLU, 1970: 85-86, doc. 97. 
a un acuerdo con el Emperador ${ }^{117}$. A pesar de que Enrique IV había intentado en varias ocasiones interponerse entre el Emperador y el Sultán, no tenía intención de complicarse en una alianza ofensiva contra España. Además de que en marzo de 1601 ya había alcanzado un acuerdo con Saboya, su intención era inflamar los sentimientos anti-hispánicos en la corte del Sultán solo cuando tenía necesidad de molestar a los españoles.

Aparte de la opción francesa, los otomanos no olvidaban el provecho que podían sacar de la lucha de los protestantes contra la Monarquía hispana. Entre los ministros otomanos existía un debate cotidiano sobre si Francia o Inglaterra era el más fiel aliado del Sultán, decisión que oscilaba al ritmo de la política internacional y de la configuración del poder en la corte otomana. Cotidianamente se recurría a jugar con la tensión existente entre Inglaterra y Francia en su rivalidad por el comercio oriental para mantener viva esta emulación. En 1597, Enrique IV había renovado las capitulaciones con la Sublime Puerta, que incluían su derecho a proteger a los comerciantes de las Provincias Unidas. Sin embargo, en abril de 1601 el Sultán revocó esta orden y concedió este derecho a Inglaterra, con la consiguiente decepción de Francia ${ }^{118}$. Esta decisión radicaba probablemente en la llegada a Estambul la noticia de la paz de Enrique IV con Saboya, que diluía las opciones de ruptura con la Monarquía hispana.

Dejando aparte la cuestión de si esta política era acertada o no, el panorama general de las relaciones franco-otomanas no cambió porque seguían estando vigentes las comunes preocupaciones estratégicas. La guerra de Saluzzo había mostrado que la coyuntura occidental podría exigir en algún momento una colaboración franco-otomana, aunque no se pusiera en práctica. La amenaza española a los franceses desde Flandes quizá no interesase mucho a los otomanos, pero las hostilidades en Italia interesaban tanto a Francia como al Sultán. Por lo tanto, los otomanos siempre estuvieron pendientes de un deterioro en las relaciones franco-españolas para que el Rey Católico desviara su interés del Norte de África. Esta ocasión se ofreció de nuevo en verano de 1602 con el descubrimiento de la conspiración de Biron. De hecho, Enrique IV se jactaba de que sus prevenciones militares contra España fueron tan efectivas que desanimaron a Felipe III para realizar un ataque contra Argel $^{119}$. A pesar de que tal afirmación careciese de toda veracidad, el Sultán apreció el gesto. El efecto de la noticia de la conjuración de Biron fue el mismo que el de la guerra de Saluzzo. A finales de 1602, Mehmed III propu-

117 SAHIN-TÓTH, 1997: 179.

118 HORNIKER, 18/4 (Chicago, 1946): 301. DE GROOT, 1978: 8.

119 «Jà le Roy d'Espagne auroit assailly la Barbarie, s'il n'eust este retenu de la crainte de mes armeés», Enrique IV a De Brèves, Paris, 11 de agosto de 1602, en XIVREY, 1850, vol. V: 654. CANO DE GARDOQUI: 1970. 
so a Enrique IV una ofensiva coordinada para castigar al Rey Católico, al que señalaban como responsable real detrás de este complot. El embajador francés en Estambul consideraba esta oferta como una fantasía y que su señor no la aceptaría $^{120}$, pero tales propuestas demostraban a Enrique IV que su política de alianza aleatoria funcionaba ${ }^{121}$.

Desde la perspectiva otomana, la probabilidad de retomar la alianza con Francia y contra los españoles sería reconfortante para el Sultán. Este se encontraba bajo la presión causada al mismo tiempo por la sublevación de los sipahi en Estambul y la rebelión de los Celali en Anatolia, problemas que debilitaban seriamente su autoridad y amenazaban a las figuras más cercanas a su persona. Tal alianza tendría un efecto balsámico sobre la política exterior otomana, porque, a pesar de algunas victorias en Hungría, como la toma de Alba Regia (actualmente, Székesfehérvár) en 1602, los otomanos se percataban de la peligrosidad de la alianza estratégica entre el Papado, la Monarquía hispana y el Imperio vigente desde 1599. La corte otomana vigilaba con mucha preocupación la reactivación de la política mediterránea de Felipe III ${ }^{122}$ en la frontera occidental ${ }^{123}$ y las negociaciones de los agentes del Shah Abbas en Praga y Roma en el frente oriental ${ }^{124}$. Por tanto no gustaría que el rey francés, su aliado tradicional, formase parte de esta política católica que se desarrollaba en los primeros años del siglo XVII.

No obstante, el rey Cristianísimo no se comprometió en la política papal porque mientras continuaran las intrigas del Rey Católico no tenía motivos para romper con el Turco, con el que sí se mantenía en paz ${ }^{125}$. Enrique IV ejercía una política basada en la razón de estado y no se podía permitir el lujo de desdeñar la alianza otomana, aunque esta fuera frágil e ineficaz. Enrique IV vio el fruto de su paciencia cuando Ahmed I subió al trono a finales de 1603. En mayo de 1604 se renovaron las capitulaciones, en las que se le restituyeron a Francia los derechos de protección exclusiva sobre los mercaderes neerlandeses ${ }^{126}$. No es casual que esto ocurriera cuando el nuevo rey de Inglaterra, Jacobo I, estaba desarrollando una política pacífica hacia España ${ }^{127}$. Sin embargo, la renovación de la alianza no significó que el rey galo volviera a

${ }^{120}$ SAHIN-TOTH, 1997: 181, n. 182.

121 DESPLAT, 1990: 397.

122 BUNES IBARRA, 2006, I: 921-946.

123 «Dell'armata Spagnola poi il Cigala ha scritto di haver inteso di novo era ritornata in Barbaria il qual di qua ha rinovato il timore di qualche mal avenimento». Agostino Nani al Senado de Venecia, Constantinopla, 18 de noviembre de 1601, ASVe, SDC, 54, n. 17.

${ }^{124}$ Agostino Nani al Dogo y Senado, Constantinopla, 20 de febrero de 1601, CSPV, vol. 9, n. 959.

125 MICHAUD, 2003: 459.

126 GROOT, 1978: 89.

${ }^{127}$ HORNIKER, 1946: 301. 
solicitar apoyo militar al Sultán: los tiempos habían cambiado y Enrique IV había recibido serias críticas por esta amistad ${ }^{128}$. Las capitulaciones de 1604 confirmaron oficialmente la reclamación francesa para proporcionar protección a los católicos del Imperio Otomano. Se depositó en el rey de Francia la responsabilidad de proteger a los peregrinos a Tierra Santa y las iglesias y los sacerdotes en tierras otomanas. La política católica que practicaba el Rey Cristianísimo no estaba marcada por un proyecto anti-turco, sino por la ambición de ser el representante de los cristianos y el protector de sus intereses en Oriente. Esto significaba, como afirma Michaud, una contemporización de la razón de estado con el imperante discurso de la protección de la Cristiandad, sin comprometerse con una cruzada anti-otomana ${ }^{129}$.

Está bien asentado el argumento de que la alianza franco-otomana se basó en el principio de la «explotación del infiel» a su propio beneficio por parte de la monarquía francesa, y que los principios de negociaciones de los monarcas franceses con los sultanes otomanos no variaron en el tiempo ${ }^{130}$. Clarence Rouillard tacha esta amistad oficial turco-francesa de ser «típicamente insincera y superficial» ${ }^{131}$. Los otomanos recurrieron también a la misma política de doble lenguaje y entretenimiento porque su máxima era también la seguridad y la conservación, a la vez que tenían que mantener su reputación contra sus enemigos y entre sus aliados. El método otomano para asegurar la fidelidad de sus aliados, ya fuera Inglaterra o Francia, era su política de capitulaciones, con la que garantizaba las ventajas materiales del comercio de Levante a sus supuestos aliados políticos. Sin embargo, aunque las promesas mutuas resultaron vanas en hechos concretos desde el inicio del reinado de Enrique IV, la alianza fue útil en el sentido de que proporcionó a cada uno protección ante la posible amenaza de su enemigo común e impedía que aparecieran frentes bélicos inesperados ${ }^{132}$.

\section{BIBLIOGRAFÍA}

Allen, Paul C., Felipe III y la pax hispánica, 1598-1621: el fracaso de la gran estrategia, Madrid, Alianza Editorial, 2001.

Andretta, Stefano, «Venezia e la fronda parlamentare in Francia (1647-1649)», en Stefano Andretta, La repubblica inquieta. Venezia nel Seicento tra Italia ed Europa, Roma, Carocci, 2000.

${ }^{128}$ SAHIN-TÓTH, 1997: 73-76; MICHAUD, 2003: 461.

129 MICHAUD, 2003: 461. POUMARÈDE, 2004: 247-254.

130 SAHIN-TOTH, 1997: 150, n. 90.

${ }^{131}$ ROUILLARD, 1940: 358; SAHIN-TÓTH, 1997: 73.

132 MICHAUD, 2003: 451. 
Benzoni, Gino, Venezia nell'età della Controriforma, Milano, Mursia, 1973.

Borromeo, Agostino, «Clément VIII, la diplomatie pontificale et la paix de Vervins», en Jean-François Labourdette et al. (eds.), Le traité de Vervins, Paris, Presses Paris Sorbonne, 2000; 323-344.

Borromeo, Agostino, «Istruzioni generali e corrispondenza ordinaria dei nunzi: obiettivi prioritari e risultati concreti della politica spagnola di Clemente VIII», en Georg Lutz (ed.), Das Papsttum, die Christenheit und die Staaten Europas. 15921605,Tubingen, Max Niemeyer, 1994; 119-233.

Bunes Ibarra, Miguel Ángel de, «Felipe III y la Defensa del Mediterráneo. La conquista de Argel», en Enrique García Hernán y Davide Maffi (eds.), Guerra y Sociedad en la Monarquía Hispánica. Política, Estrategia y Cultura en la Europa Moderna (1500-1700), vol. I, Madrid, Ediciones del Laberinto, 2006; 921-946.

Cano de Gardoqui, José Luis, La conspiración de Biron, 1602: tensiones hispanofrancesas en el siglo XVII, Valladolid, Universidad, 1970.

Cessi, Roberto, «Venezia e Puglia nel sistema Adriatico del passato», Archivio Storico Pugliese, 5 (Bari, 1952), 237-242.

Coles, Paul, The Ottoman Impact on Europe, London, Thames and Hudson, 1968.

Desplat, Christian, «Henri IV et les Ottomans», en Avènement d'Henri IV. Quatrième centenaire. Colloque III. Henri IV: le roi et la reconstruction du royaume, Pau, Association Henri IV, 1990; 395-422.

De Groot, Alexander H., The Ottoman Empire and the Dutch Republic: a History of the Earliest Diplomatic Relations, 1610-1630, Leiden, Nederlands HistorischArchaeologisch Instituut, 1978.

Dursteler, Eric, Venetians in Constantinople: Nation, Identity, and Coexistence in the Early Modern Mediterranean, Baltimore, The Johns Hopkins University Press, 2006.

Fisher-Galati, Stephen A., Ottoman Imperialism and German Protestantism 15211555, Cambridge, Harvard University Press, 1959.

Flemming, Barbara, «Khodja Efendi Sa'd Al-Din», Encyclopedia of Islam, V, Leiden, E.J. Brill, 1979; 27-28.

Fodor, Pal, «Between Two Continental Wars: the Ottoman Naval Preparations in 1590-1592», en Pal Fodor (ed.), In Quest of the Golden Apple. Imperial Ideology, Politics, and Military Administration in the Ottoman Empire, Istanbul, Isis Press, 2000; 171-190.

González Cuerva, Rubén, «Cruzada y dinastía: las mujeres de la Casa de Austria ante la Larga Guerra de Hungría», en José Martínez Millán (dir.), Las relaciones discretas entre las monarquías hispana y portuguesa, Madrid, Polifemo, 2009; 1149-1186.

Gullino, G. «Girolamo Lippomano», Dizionario Biografico degli Italiani, 65, Roma, Istituto della Enciclopedia Italiana, 1981; 241-242.

Horniker, Arthur Leon, «Anglo-French Rivalry in the Levant from 1583 to 1612», Journal of Modern History, 18/4 (Chicago, 1946), 289-305. 
Hurewitz, Jacob C., «Ottoman Diplomacy and the European States System», The Middle East Journal, 15/2 (Washington, 1961), 141-152.

Isom-Verhaaren, Christine, Allies with the Infidel: The Ottoman and French Alliance in the Sixteenth Century, London, I.B. Tauris, 2011.

Isom-Verhaaren, Christine, ««Barbarossa and His Army Who Came to Succor All of Us»: Ottoman and French Views of Their Joint Campaign of 1543-1544», French Historical Studies, 30/3 (Durham, 2007), 395-425.

Jensen, De Lamar, «The Ottoman Turks in Sixteenth Century French Diplomacy», The Sixteenth Century Journal, 16/ 4 (Missouri, 1985), 451-470.

Kurat, Akdes Nimet, Türk-Ingiliz Münasebetlerinin Başlangıcı ve Gelişmesi, 15531610, Ankara, Ankara Üniversitesi Dil ve Tarih-Coğrafya Fakültesi, 1953.

Lesure, Michel, «Les relations franco-ottomanes a l'épreuve des guerres de religion (1560-1594)», en Hamit Batu y Jean Luis Bacqué-Grammont (eds.) L'Empire Ottoman, la république de Turquie et la France, Istanbul-Paris, Isis Press, 1986; 37-57.

Michaud, Claude, «Henri IV, le pape Clément VIII et les Turcs», en Daniel TOLLET (ed.), Guerres et paix en Europe centrale aux époques moderne et contemporaine: mélanges d'histoire des relations internationales offers à Jean Bérenger, Paris, Université de Paris-Sorbonne, 2003; 237-251.

Niederkorn, Jan Paul, «Gesandte - Vermittler - Schwindler. Von den Schwierigkeiten diplomatischer Kontakte mit orientalischen und osteuropäischen Mächten in der frühen Neuzeit», Österreichische Osthefte, $37 / 4$ (Viena, 1995), 863-878.

Niederkorn, Jan Paul, Die europäischen Mächte und der «Lange Türkenkrieg» Kaiser Rudolfs II (1593-1606), Viena, Verlag der Osterreichischen Akademie der Wissenschaften, 1993.

Orhonlu, Cengiz, Osmanl Tarihine Aid Belgeler: Telhisler (1597-1606), Istanbul, İstanbul Üniversitesi Edebiyat Fakültesi Yayınlar1, 1970.

Özbaran, Salih, The Ottoman Response to European Expansion: Studies on OttomanPortuguese Relations in the Indian Ocean and Ottoman Administration in the Arab lands during the Sixteenth Century, Istanbul, Isis Press, 1994.

Pedani-Fabris, Maria Pia (ed.), Relazioni di ambasciatori veneti al senato, Vol. 14: Costantinopoli, Relazioni inedite (1512-1789), Padua, Bottega d'Erasmo, 1996.

Podea, I. I., «A Contribution to the Study of of Queen Elizabeth's Eastern Policy (1590-1593)», en Constantin Marinescu (ed.), Melanges d'Histoire Generale, II, Cluj, 1938; 423-476.

Poumarède, Géraud, Pour en finir avec la Croisade: mythes et réalités de la lutte contre les Turcs aux XVIe et XVIIe siècles, Paris, Presses Universitaires de France, 2004.

Rigault, Abel, «Savary de Lancosme. Un épisode de la Ligue a Constantinople (1589-1593)», Revue d'histoire diplomatique, 16 ( Paris, 1902), 522-578.

Rivero Rodríguez, Manuel, La España de Don Quijote: un viaje al Siglo de Oro, Madrid, Alianza, 2005. 
Rodríguez Salgado, María José, Felipe II, «el Paladín de la Cristiandad» y la paz con el turco, Valladolid, Universidad de Valladolid, 2004.

Rouillard, Clarence D., The Turk in French history, thought, and literature (15201660), Paris, Boivin, 1940.

Ruiz Ibáñez, José Javier, «Cette disgrace de guerre. La opción española en la política francesa de 1598 a 1635», en Porfirio Sanz Camañes (ed.), La monarquía hispánica en tiempos del Quijote, Madrid, Silex, 2005; 529-555.

Ruiz Ibáñez, José Javier, Esperanzas y fracasos de la política de Felipe II en Francia (1595-1598): la historia entre la fe y las armas jornaleras, Murcia, Quaderna editorial, 2004.

Ruiz Ibáñez, José Javier, «Le choix du Roi. Les limites de l'intervention espagnole en France (1592-1598)», en Claudine Vidal y Frédérique Pilleboue (eds.), La paix de Vervins (1598), Amiens, Féderation des Sociétes d' Histoire et d' Archéologie de l' Aisne, 1998; 138-158.

Sahillioğlu, Halil, Koca Sinan Paşa'nın Telhisleri, IRCICA, Istanbul, 2004.

Sahin-Tóth, Péter, La France et les Français face à la «longue guerre» de Hongrie (1591-1606), tesis doctoral inédita, Université François Rabelais de Tours, 1997.

Selaniki Mustafa Efendi, Tarih-i Selaniki, Mehmet İpşirli (ed.), Istanbul, Türk Tarih Kurumu, 1989.

Skilliter, Susan, William Harborne and the Trade with Turkey, 1578-1582, London, Oxford University Press, 1977.

Türkçelik, Evrim, Cigalazade Yusuf Sinan Pasha y el Mediterráneo entre 1591-1606, tesis doctoral inédita, Universidad Áutonoma de Madrid, 2012.

Vaughan, Dorothy M., Europe and the Turk: A Pattern of Alliances, 1350-1700, Liverpool, Liverpool University Press, 1954.

Vázquez De Prada, Valentín, Felipe II y Francia: política, religión y razón de estado, Pamplona, Eunsa, 2004.

Veinstein, Gilles, «Les ambiguities de l'alliance franco-ottomane», en Mohammed Arkoun (ed.), Histoire de l'islam et des musulmans en France du Moyen Âge à nos jours, Paris, Éditions Albin Michel, 2006; 344-379.

Veinstein, Gilles, «Les préparatifs de la campagne navale franco-turque en 1552 à travers les ordres du divan ottoman», Revue de l'Occident musulman et de la Méditerranée, 39 (Aix-en-Provence, 1985), 35-67.

Visceglia, Maria Antonietta, «La corte de Roma», en Maria Antonietta Visceglia y José Martínez Millán (dirs.), La monarquía de Felipe III, vol. IV, Madrid, Fundación MAPFRE, 2008; 947-1011.

Weis, Gillian Lee, Captives and corsairs: France and slavery in the early modern Mediterranean, Stanford, Stanford University Press, 2011.

Wernham, Richard B., The Return of the Armadas: the Last Years of the Elizabethan War against Spain, 1595-1603, Oxford, Clarendon Press, 1994. 
Yurdusev, A. Nuri, «The Ottoman Attitude toward Diplomacy», en A. Nuri Yurdusev (ed.), Ottoman Diplomacy: Conventional or Unconventional? Londres, Palgrave, 2004; 5-35.

Xivrey, Jules Berger de, Recueil des lettres missives de Henri IV: 1593-1598, IV, Paris, Imprimerie Royale, 1846.

Xivrey, Jules Berger de, Recueil des lettres missives de Henri IV: 1599-1602, V, Paris, Imprimerie Royale, 1850.

Recibido: 03/09/2013

Aceptado: 16/06/2014 